\title{
Plasmacytoid Urothelial Carcinoma of the Bladder: Case Report and Review of the Literature
}

\section{Carcinoma urotelial de vejiga, variante plasmocitoide: Reporte de un caso y revisión de la literatura}

\author{
Ángela Molina Barrera ${ }^{1}$ Andrea Vásquez Franco $^{2}$ Andrés Felipe Aristizábal ${ }^{2}$ David Correa Galeano ${ }^{2}$ \\ Manuel Cabrales Hessen² \\ ${ }^{1}$ Resident, Urology, Universidad de Antioquia, Medellín, Antioquia, \\ Address for correspondence Ángela Marcela Molina Barrera, Calle \\ Colombia \\ 2 Urology, Clínica León XIII, Medellín, Antioquia, Colombia \\ 51B \#69-13 Clínica León XIII, Bloque 1, piso 4 Norte, Departamento de \\ Urología, Medellín, Antioquia, Colombia \\ (e-mail: angelamolinab@hotmail.com).
}

Urol Colomb 2019;28:333-337.

\begin{abstract}
Keywords

- plasmacytoid urothelial carcinoma

- urothelial carcinoma

- bladder

- treatment

- prognosis
\end{abstract}

Resumen
Introduction Plasmacytoid urothelial carcinoma (PUC) of the bladder is a rare histological variant, accounting for 1 to $3 \%$ of the invasive urothelial carcinomas, and it is typically aggressive. So far, it has not been well characterized, and the literature is based on reports and case series.

Case Report A 70-year-old male patient presenting with 4 months of constitutional and urinary symptoms, with an ultrasound finding of bilateral hydronephrosis and diffuse thickening of the bladder walls. In the cystoscopy, trigone of infiltrated appearance, a biopsy wass performed, whose immunohistochemistry revealed a PUC. The abdominopelvic image showed an infiltrative lesion that compromised the muscle of the bladder and extended to the perivesical fat, without adequate plane of cleavage with the prostate and a single hypogastric adenopathy suspected of malignancy. It was classified as cT3b vs CT4aN1M0 (chest computed tomography [CT] negative for malignancy), and the patient was submitted to a radical cystoprostatectomy, extended pelvic lymphadenectomy and non-continent urinary diversion with ileal conduit. The pathology revealed a diffuse PUC with prostatic stromal involvement and 22 of 39 lymph nodes positive for malignancy. Finally, the patient presented a series of postoperative complications and died.

Conclusion Plasmacytoid urothelial carcinoma of the bladder is a rare entity, characterized by high aggressiveness, an advanced stage at the time of diagnosis, and a poor prognosis. Currently, an aggressive approach is recommended due to its high invasive potential.

Introducción El carcinoma urotelial plasmocitoide (CUP) de la vejiga es una variante histológica poco frecuente; representa el 1 al $3 \%$ de los carcinomas uroteliales invasivos y es típicamente agresiva. Hasta el momento no ha sido bien caracterizada, y la literatura se basa en reportes y series de casos. received

July 7, 2018

accepted

November 29, 2018
DOI https://doi.org/

10.1055/s-0038-1677034

ISSN $0120-789 X$

e ISSN 2027-0119.
Copyright ( 2019, Sociedad Colombiana License terms de Urología. Publicado por Thieme Revinter Publicações Ltda., Rio de Janeiro, Brazil. Todos los derechos reservados.

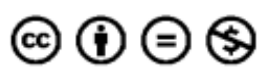




\section{Palabras-clave}

- carcinoma urotelial plasmocitoide

- carcinoma urotelial

- vejiga

- tratamiento

- pronóstico
Reporte de Caso Paciente masculino de 70 años presentando por 4 meses síntomas constitucionales y urinarios, con hallazgo ecográfico de hidronefrosis bilateral y engrosamiento difuso de las paredes vesicales. En la cistoscopia, trígono de apariencia infiltrada, se realizó biopsia cuya inmunohistoquímica reveló un CUP. En imagen abdominopélvica, se evidenció lesión infiltrativa que comprometía la muscular de la vejiga y se extendía a la grasa perivesical, sin adecuado plano de clivaje con la próstata y un único ganglio hipogástrico sospechoso de malignidad. Se clasificó como cT3b vs cT4aN1M0 (TAC tórax negativo para malignidad) y fue llevado a cistoprostatectomía radical, linfadenectomía pélvica extendida y derivación urinaria no continente con conducto ileal. La patología reveló un carcinoma urotelial variante difusa plasmocitoide con compromiso de estroma prostático y 22 de 39 ganglios positivos para malignidad. Finalmente, el paciente presentó una serie de complicaciones posoperatorias y falleció. Conclusión El carcinoma urotelial de vejiga variante plasmocitoide es una entidad poco frecuente, caracterizada por alta agresividad, un estadio avanzado al momento del diagnóstico, y un pobre pronóstico. En la actualidad, se recomienda un enfoque agresivo dado su alto potencial invasivo.

\section{Introduction}

\section{Epidemiology}

Bladder cancer is the most frequent neoplasia affecting the urinary tract, and the 9th neoplasia diagnosed worldwide. ${ }^{1}$ Most bladder malignancies present as epithelial tumors, with $90 \%$ of the cases being urothelial. ${ }^{2}$ In recent decades, multiple variants of this type of tumor have been investigated, and some properties regarding their treatment and prognosis have been described. $^{2}$

Plasmacytoid urothelial carcinoma (PUC) of the bladder is a rare histological variant of the urothelial carcinoma (UC). It was recognized by the World Health organization (WHO) in 2004..$^{3,4}$ Its first description was made by Sahin et al in 1991.5,6 The incidence of PUC is higher in males (3:1), with a mean diagnosis age of 69 years old, and represents between 2.7 and $3 \%$ of all urothelial bladder cancers. ${ }^{7,8}$ There have been less than 100 cases described in the literature; ${ }^{6}$ therefore, the biology, prognosis and treatment of this pathology are still hard to establish. ${ }^{9}$ It is considered a very aggressive variant with a tendency to recur and to develop metastasis early in its course, 5,10 presenting with invasion at the time of the diagnosis in $81.9 \%$ of the cases. ${ }^{11}$ Keck et al published one of the largest series of cases ( 32 cases), proving PUC to be high grade in $100 \%$ of the patients, and with distant metastasis at the time of the diagnosis in $60 \%$ of the cases. ${ }^{12}$

\section{Clinical Presentation}

The clinical presentation of PUC is frequently late onset. ${ }^{5}$ Its main debut symptom is hematuria; however, it will only appear in late stages. Other symptoms include: urgency, urinary frequency increase, and low abdominal pain. ${ }^{8} \mathrm{Me}-$ tastasis often affects adjacent pelvic structures such as the bones, the peritoneum, the gastrointestinal tract, and the scrotum, 3,6,13,14 and even heart distant metastasis have been described. ${ }^{15}$ Ricardo-Gonzalez et al evaluated 15 patients with PUC and found this tumor presenting with recurring extension to the peritoneum, often compromising serous surfaces. $^{16}$

One of the hypotheses for the aggressiveness of this tumor and its extension pattern is the loss of Ecadherin (a necessary protein for cell to cell adhesion), 6,17 which is absent in most PUCs and can help distinguish it from other types of UCs. ${ }^{11}$ It is postulated that the absence of E-cadherin leads to loss of cellular differentiation, allowing the PUC cells to invade the surrounding tissues along the fascial planes and toward the lymph nodes. $^{14,18}$

\section{Case Report}

We present the case of a 70-year-old male patient, hypertensive, who arrived at the consultation reporting 4 months of constitutional symptoms (asthenia, adynamia, weight loss), decrease in urinary stream gage, post urination drip, nycturia, rectal exam negative for malignancy, and an ecographic finding of thickened bladder walls and bilateral hydronephrosis. Bilateral nephrostomies were placed, and a cystoscopy was performed, revealing an infiltrated-like trigone, without defined masses. The results of this tissue biopsy reported carcinomatosis.

Immunohistochemistry studies of this biopsy evaluated cytokeratin 7 (CK7), cytokeratin 20 (CK20), endothelial transcription factor 3 (GATA3), cytokeratin 5/6 (CK 5/6), P63, prostate-specific antigen (PSA) and prostate-specific acid phosphatase (PSAP), resulting positive for CK7 and GATA3, supporting the diagnosis of PUC.

An infiltrative lesion is shown in the magnetic resonance imaging (MRI) (-Figs. 1 and $\mathbf{2}$ ) on the posterior and lateral walls of the bladder, extending to the perivesical fat, infiltrating ureterovesical junction and resulting in hydroureteronephrosis. It relates to the prostate gland 


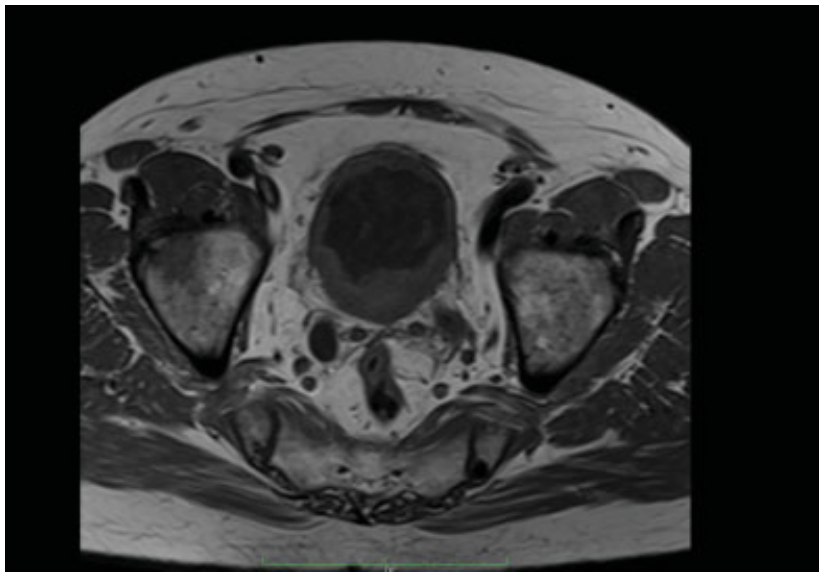

Fig. 1 Lesion with infiltrating aspect on the posterior wall of the bladder.

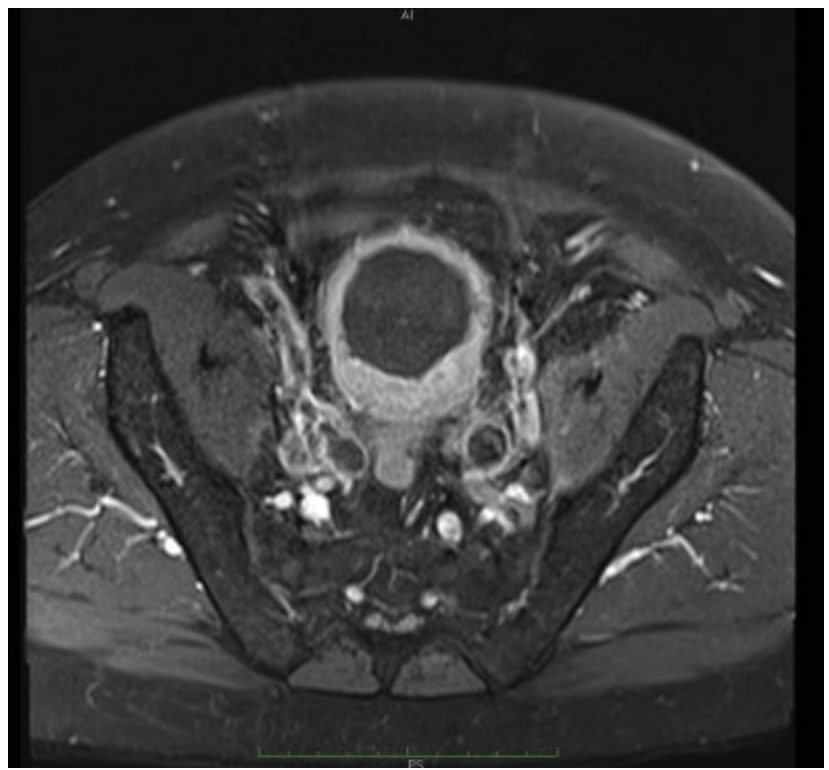

Fig. 2 Lesion with infiltrating aspect on the lateral walls of the bladder.

without an adequate cleavage plane, with a sole hypogastric node of $7 \mathrm{~mm}$, suspicious of malignancy. The lesion was classified as CT3b vs cT4aN1M0. A computed tomography $(\mathrm{CT})$ of the chest was negative for pulmonary metastasis.

The patient was submitted to radical cistoprostatectomy, extended pelvic lymphadenectomy, and non-continent urinary heterotopic derivation, with the intention of performing adjuvant chemotherapy later. During the surgery, we observed both ureters with macroscopic compromise in their distal third. However, the freeze biopsy turned out negative for malignancy.

Pathology samples ( $\mathbf{- F i g s . ~} 3$ and $\mathbf{4}$ ) note: PUC, invading the perivesical tissue and compromising the stroma of the prostate, the left ureter, and the left seminal vesicle. Lymphovascular invasion present. Out of a total of 39 nodes, 22 were compromised by the carcinoma.

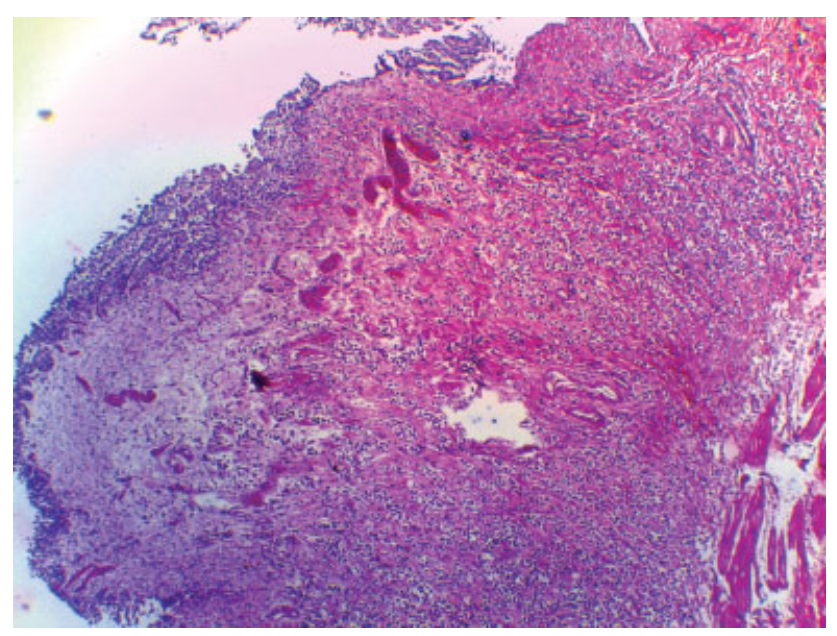

Fig. 3 Tumor with urothelial origin, invading the muscle of the bladder.

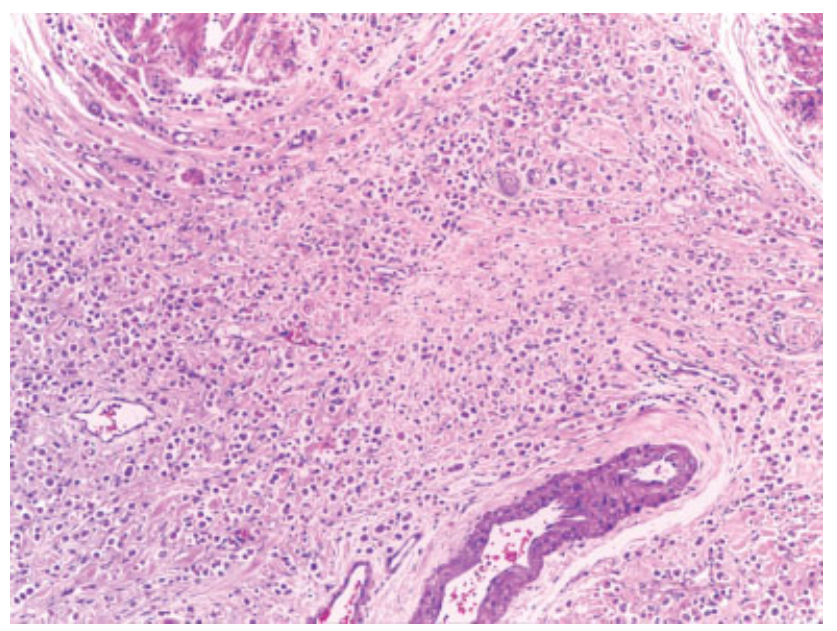

Fig. 4 Tumor cells; notice the big cell nucleus, the discohesive pattern, and the plasmacytoid morphology.

During the evolution of the disease, the patient developed postoperative ileus and required reoperation for an unnoticed rectum lesion, presenting fecal peritonitis, abdominal sepsis, and eventual death 14 days after the first intervention.

\section{Discussion}

\section{Diagnosis}

Plasmacytoid urothelial carcinoma of the bladder is often diagnosed at a late stage due to the absence of hematuria and of a bladder tumor identifiable by conventional methods. Cystoscopic findings are usually mucosal induration and thickened vesical wall, ${ }^{19,20}$ although other series describe focal masses. ${ }^{21,22}$ In the case described in the present article, the patient presented with unspecific symptoms, never with hematuria, and the cystoscopic findings only revealed an infiltrated trigone.

Histologically, this tumor is characterized by a discohesive growth of cells with plasmacytoid morphology, with eccentric nucleus and eosinophilic cytoplasm, frequently extending to the vesical floor and to the perivesical fat tissue. ${ }^{21}$ The architectural 
patterns of PUC may vary. Cells may present in simpler lines, small nests or discohesive patterns diffusely disposed in layers. ${ }^{23}$ These aggressive growth patterns explain the poor prognosis of PUC. ${ }^{23}$ When the histological appearance is highly suspicious of PUC, immunohistochemistry plays a key role in the diagnosis, ${ }^{2}$ since the PUC cells present cytoplasmic immunoreactivity to cytokeratins, especially those with high molecular weight, of which CK7 and CK20) play an important role. CD138 is a cytoplasmic cellular differentiation marker also positive in PUC. ${ }^{24,25}$ Other patterns of immunohistochemistry found in PUC are: CK8, CK18, CK19, 34ßE12, CD15, and GATA3.

Generally, this pathology is negative for the common antigens found in leucocytes: multiple myeloma-1/interferon regulatory factor-4 (MUM1/IRF4), light chains, human melanoma black-45 (HMB-45), S-100, desmin, chromogranin, synaptophysin, vimentin, and specific prostatic antigens. ${ }^{20,21,26,27}$

Recently, GATA3 has shown to be of value in UC, including PUC. $^{3,22}$ Zhao et al reported high specificity of GATA3 as a diagnostic marker in PUC, showing a higher expression in regional metastasis. ${ }^{28}$ Therefore, GATA3 seems to be an appropriate marker for differential diagnosis, useful in recognizing the urothelial lineage of PUC in metastatic patients. ${ }^{29}$ In our case, CK7 and GATA3 were positive.

The differential diagnosis of PUC includes other tumors with plasmacytoid morphology, such as plasmacytoma, lymphoma, diffuse gastric cancer, breast lobular cancer, neuroendocrine carcinoma, and rhabdomyosarcoma. ${ }^{21,23}$

\section{Treatment}

The therapeutic approach for this pathology remains in discussion due to its rarity. So far, due to the few cases reported in the literature, there are no clear guides for the treatment of PUC. ${ }^{21}$ Radical cystectomy is considered the first line of treatment for PUC when it is non-metastatic or non-muscle-invading. ${ }^{5} \mathrm{~A}$ possible benefit with adjuvant chemotherapy is also suggested. ${ }^{20}$

The role of chemotherapy as a neoadjuvant for PUC remains uncertain; only a small number of cases have been published on this subject. ${ }^{11,26,30}$ Kohno et al described an advanced case of PUC with complete response to neoadjuvant chemotherapy with two cycles of methotrexate, etoposide, vinblastine and cisplatin. ${ }^{31,34}$ This data is consistent with the latest study by Gunaratne et al, which reports the case of another patient with muscle-invading PUC treated with four cycles of chemotherapy with gemcitabine and cisplatin, leading to a complete histologic response (pT0). ${ }^{30}$

The optimal scheme of chemotherapy in this pathology persists to be concerted, used as a neoadjuvant. Preliminary researches indicate satisfactory results, although larger and longer follow-up studies are needed. ${ }^{30}$

\section{Prognosis}

The diagnosis of late onset PUC indicates a poor prognosis, especially because a third of the cases are metastatic at the time of presentation. ${ }^{11,32}$

In a series of 30 patients, the mean global and specific survival rate was of 19 and 22 months respectively. ${ }^{18}$ Another series of 31 patients found a mean survival rate of 17.7 months. ${ }^{11}$
Cockerill et $\mathrm{al}^{33}$ evaluated results after radical cystectomy in patients with PUC compared with a control group with pure UC. It was found that the PUC patients had more extravesical disease ( $\geq$ pT3) (83 versus 43\%) and more positive margins at the surgery stage (31 versus $2.1 \%$ ). Additionally, PUC was associated with a smaller global survival rate $(27 \%$ versus $45 \%$ at 5 years, risk ratio [RR]: 1,$4 ; p=0.04)$, a smaller specific survival rate than cancer (36\% versus $57 \%$ at 5 years, RR: 1,7 ; $p=0.01$ ), and a smaller survival free of local recurrence $(63 \%$ versus $81 \%$ at 5 years, RR: $2 ; p=0.01) .{ }^{33}$ Kaimakliotis et al ${ }^{18}$ found in their study a greater incidence of positive ureteral margins in patients with PUC (32\%) when compared with patients with conventional UC (3.7\%) or with the micropapillary variant (17.9\%), resulting in statistically significant data. ${ }^{18}$

\section{Conclusion}

Plasmacytoid urothelial carcinoma is a very infrequent variant of urothelial carcinoma, with very few reports in the literature; because of this, its biology, prognosis and treatment are not clearly established. It is considered a very aggressive variant, with a tendency to recur and to present metastasis at an early stage. Its diagnosis is generally late, due to clinical manifestations happening in advanced disease cases and cystoscopic findings resulting unspecific most of the times. Its histologic characteristic is discohesive growth of plasmacytoid morphology cells, with a generally invading behavior. In immunochemistry stains, these cells are positive for different markers, which enable their distinction from conventional UC. The therapeutic approach remains in discussion due to the rarity of this tumor. Radical cystectomy is the gold standard treatment in muscleinvasive tumors without metastasis. Chemotherapy has been used as a neoadjuvant and adjuvant treatment, so far with promising results. However, larger studies are required to draw conclusions and to reach a consensus.

Note

The present study was conducted at IPS Universitaria Clínica León XIII, Medellín - Antioquia, Colombia.

\section{Ethical Considerations}

The present work followed the rules for research with human being according to what is provided by resolution no $008430 / 1993$ in the 2013 Declaration of Helsinki. It was a non-experimental research with minimal risk. Even though the main goal of medical researches is to produce new knowledge, this goal will never prevail over the rights and interests of the people participating in them.

\section{Conflicts of Interests}

The authors have no conflict of interests to declare.

\section{References}

1 Citarella D, Quiroga W, Fernandez F, Pati I. Bladder cáncer guidelines y Andrea Estrada. Guía de Manejo en Cáncer Vesical 2016;25 (02):154-168

2 Aldousari S, Sircar K, Kassouf W. Plasmacytoid urothelial carcinoma of the bladder: a case report. Cases J 2009;2:6647 
3 Brustmann H. Plasmacytoid Urothelial Carcinoma of the Urinary Bladder Metastatic to the Duodenum: A Case Report-Diagnostic Relevance of GATA3 Immunohistochemistry. Case Rep Pathol 2017;2017:5209059

4 Lopez-Beltran A, Requena MJ, Montironi R, Blanca A, Cheng L. Plasmacytoid urothelial carcinoma of the bladder. Hum Pathol 2009;40(07):1023-1028

5 Velis JM, Barba JF, Tienza A, Queipo FJ, Sola JJ, Zudaire JJ. [Plasmacytoid variant of urothelial carcinoma: a case report]. An Sist Sanit Navar 2013;36(02):357-361

6 Nabbout P, Furr J, Paari M, Slobodov G. Plasmacytoid urothelial carcinoma of the bladder metastatic to the stomach: a case report. Case Rep Urol 2012;2012:715951

7 Zhao L, Antic T, Witten D, et al. Is GATA3 expression maintained in regional metastases?: a study of paired primary and metastatic urothelial carcinomas Am J Surg Pathol 2013;37(12):1876-1881

8 Wang Z, Lu T, Du L, et al. Plasmacytoid urothelial carcinoma of the urinary bladder: a clinical pathological study and literature review. Int J Clin Exp Pathol 2012;5(06):601-608

9 Ro JY, Shen SS, Lee HI, et al. Plasmacytoid transitional cell carcinoma of urinary bladder: a clinicopathologic study of 9 cases. Am J Surg Pathol 2008;32(05):752-757

10 Li Q Assel M, Benfante NE, et al. The Impact of Plasmacytoid Variant Histology on the Survival of Patients with Urothelial Carcinoma of Bladder after Radical Cystectomy. Eur Urol Focus 2017;1(646):1-5

11 Foley NH, Bray I, Watters KM, et al. NIH Public Access. Cell 2012;18 (07):1089-1098

12 Keck B, Stoehr R, Wach S, et al. The plasmacytoid carcinoma of the bladder-rare variant of aggressive urothelial carcinoma. Int J Cancer 2011;129(02):346-354

13 Jibril A, Stevens AC. Plasmacytoid Urothelial Carcinoma of Ureter with Retroperitoneal Metastasis: A Case Report. Am J Case Rep 2018;19:158-162

14 da Fonseca LG, Souza CE, Mattedi RL, Girardi DM, Sarkis ÁS, Hoff PMG. Plasmacytoid urothelial carcinoma: a case of histological variant of urinary bladder cancer with aggressive behavior. Autops Case Rep 2014;4(04):57-61

15 Peck JR, Hitchcock CL, Maguire S, Dickerson J, Bush C. Isolated cardiac metastasis from plasmacytoid urothelial carcinoma of the bladder. Exp Hematol Oncol 2012;1(01):16

16 Ricardo-Gonzalez RR, Nguyen M, Gokden N, Sangoi AR, Presti JC Jr, McKenney JK. Plasmacytoid carcinoma of the bladder: a urothelial carcinoma variant with a predilection for intraperitoneal spread. J Urol 2012;187(03):852-855. Doi: 10.1016/j.juro.2011.10.145

17 Fox MD, Xiao L, Zhang M, et al. Plasmacytoid Urothelial Carcinoma of the Urinary Bladder: A Clinicopathologic and Immunohistochemical Analysis of 49 Cases. Am J Clin Pathol 2017;147(05):500-506

18 Kaimakliotis HZ, Monn MF, Cheng L, et al. Plasmacytoid bladder cancer: variant histology with aggressive behavior and a new mode of invasion along fascial planes. Urology 2014;83(05): $1112-1116$

19 Mai KT, Park PC, Yazdi HM, et al. Plasmacytoid urothelial carcinoma of the urinary bladder report of seven new cases. Eur Urol 2006;50(05):1111-1114
20 Fritsche HM, Burger M, Denzinger S, Legal W, Goebell PJ, Hartmann A. Plasmacytoid urothelial carcinoma of the bladder: histological and clinical features of 5 cases. J Urol 2008;180 (05):1923-1927

21 Raspollini MR, Sardi I, Giunti L, et al. Plasmacytoid urothelial carcinoma of the urinary bladder: clinicopathologic, immunohistochemical, ultrastructural, and molecular analysis of a case series. Hum Pathol 2011;42(08):1149-1158

22 Chung AD, Schieda N, Flood TA, et al. Plasmacytoid urothelial carcinoma (PUC): Imaging features with histopathological correlation. Can Urol Assoc J 2017;11(1-2):E50-E57

23 Nigwekar P, Tamboli P, Amin MB, Osunkoya AO, Ben-Dor D, Amin MB. Plasmacytoid urothelial carcinoma: detailed analysis of morphology with clinicopathologic correlation in 17 cases. Am J Surg Pathol 2009;33(03):417-424

24 Olsen DL, Anderson SR. Metastatic plasmacytoid urothelial carcinoma: a case report and review of the literature. Acta Cytol 2014; 58(01):108-112

25 Devrim T, Atac F, Altunkaya C, Ozbek A, Ozdemir G, Eryol M. Rare Plasmacytoid Urothelial Carcinoma of the Bladder: Two Case Reports. Urol J 2018. Doi: 10.22037/uj.v0i0.4084

26 Hayashi T, Tanigawa G, Fujita K, et al. Two cases of plasmacytoid variant of urothelial carcinoma of urinary bladder: systemic chemotherapy might be of benefit. Int J Clin Oncol 2011;16 (06):759-762

27 Mitsogiannis IC, Ioannou MG, Sinani CD, Melekos MD. Plasmacytoid transitional cell carcinoma of the urinary bladder. Urology 2005;66(01):194

28 Zhao L, Antic T, Witten D, et al. Is GATA3 expression maintained in regional metastases?: a study of paired primary and metastatic urothelial carcinomas Am J Surg Pathol 2013;37(12):1876-1881

29 Paner GP, Annaiah C, Gulmann C, et al. Immunohistochemical evaluation of novel and traditional markers associated with urothelial differentiation in a spectrum of variants of urothelial carcinoma of the urinary bladder. Hum Pathol 2014;45(07): $1473-1482$

30 Gunaratne DA, Krieger LEM, Maclean F, Vaux KJ, Chalasani V. Neoadjuvant Chemotherapy with Gemcitabine and Cisplatin for Plasmacytoid Urothelial Bladder Cancer: A Case Report and Review of the Literature. Clin Genitourin Cancer 2016;14(01): e103-e105

31 Aldousari S, Sircar K, Kassouf W. Plasmacytoid urothelial carcinoma of the bladder: a case report. Cases J 2009;2:6647

32 Kalogeraki A, Tamiolakis D, Ieromonahou P, Georghiou G, Karvela-Kalogeraki I, Giannikaki E. Plasmacytoid urothelial carcinoma of the bladder with peritoneal spread. Cytological diagnosis in ascitic fluid. Actas Urol Esp 2015;39(04):268-269. Doi: 10.1016/j.acuro.2014.07.005 [Internet]

33 Cockerill APA, Cheville JC, Boorjian SA, et al. Outcomes Following Radical Cystectomy for Plasmacytoid Urothelial Carcinoma: Defining the Need for Improved Local Cancer Control. Urology 2017;102:143-147

34 Kohno T, Kitamura M, Akai H, Takaha M, Kawahara K, Oka T. Plasmacytoid urothelial carcinoma of the bladder. Int J Urol 2006; 13:485-486 